\title{
Fetus acardius amorphous: a rare case report
}

\author{
Dharitri M. Bhat*, Pradip R. Butale, Dinkar T. Kumbhalkar, Waman K. Raut
}

Department of Pathology, Government Medical College Nagpur, Maharashtra, India

Received: 02 September 2017

Accepted: 11 September 2017

\section{*Correspondence:}

Dr. Dharitri M. Bhat,

E-mail: dharitribhat@gmail.com

Copyright: () the author(s), publisher and licensee Medip Academy. This is an open-access article distributed under the terms of the Creative Commons Attribution Non-Commercial License, which permits unrestricted non-commercial use, distribution, and reproduction in any medium, provided the original work is properly cited.

\begin{abstract}
Fetus acardius amorphous is a rare fetal malformation, lacking a functional heart and bearing no resemblance to human embryos. The main differential diagnosis is with placental teratoma and is based on the degree of skeletal organization and umbilical cord formation. A 27-year old woman delivered a healthy newborn at 36 weeks gestation. An oval well defined mass, covered with normal looking skin, was connected to the placenta with a thin walled vessel. X-ray examination of the mass revealed the presence of vertebral column. Histopathologic examination demonstrated the presence admixture of tissues including neural tissue, osteoid, cartilage, muscle, fat etc. beneath the skin. The rarity of fetal monsters without a functioning heart is emphasized.
\end{abstract}

Keywords: Acardius, Fetus, Teratoma

\section{INTRODUCTION}

Acardiac twin is a rare complication of monozygotic twin pregnancies occurring in $1 \%$ of monochorionic twin gestations with an incidence of 1 in 35,000 births and perinatal mortality of 50 to $70 \%$ without treatment. ${ }^{1}$ It is characterized by presence of a recipient fetus exhibiting lethal anomalies including acardia and a pump fetus which is anatomically normal. Mortality is usually due to heart failure or premature labor caused by polyhydramnios of pump fetus. ${ }^{2}$

The pump twin is anatomically normal but usually shows features of congestive cardiac failure. In acardiac twin, development is limited in only the lower part of the body of which the blood supply is provided from hypoxic blood. ${ }^{3}$ Simonds and Gowen have proposed a classification of these fetal abnormalities into five types (amorphous, mylacephalus, acormus, acephalus and anceps or paracephalus) depending on the extent of development of fetal structures. ${ }^{4}$ Acardiac amorphous fetus has no identifiable organs. It is as an amorphous tissue mass and it consists approximately $5 \%$ of all cases. ${ }^{5}$ Antenatal diagnosis may be made by absence of the heart on ultrasound at the end of the first trimester and revealing placental vascular anastomosis with Doppler despite presence of trunk and extremity movements in the twin that has multiple anomalies. ${ }^{6,7}$ Doppler studies may show pathognomonic features of reverse flow on artery-artery anastomosis. ${ }^{8}$

\section{CASE REPORT}

A 27-year-old primigravida came to casualty of our tertiary health care center with history of amenorrhea of 8 and $1 / 2$ months with labour pains. She hailed from a small town and was visiting for ANC checkup regularly. She was non-diabetic, nonhypertensive. Her first trimester ultrasound was within normal limits. When she turned up for ultrasound examination in last trimester, it showed a tumor near fetal neck. Diagnosis was kept as? Meningocele? Teratoma. As she had fetal distress, she was immediately taken for emergency caesarean section. A full term normal baby weighing $2.4 \mathrm{~kg}$ was delivered by lower segment caesarean section (LSCS). A tumor of $15 \times 10 \times 8 \mathrm{~cm}$ was seen attached to placenta. The tumor 
along with placenta was sent for histopathological examination.

\section{Gross examination}

We received placenta of size $18 \times 12 \times 7 \mathrm{~cm}$ with umbilical cord of $14 \mathrm{~cm}$ long. Another thin walled vessel was seen connecting placenta to the tumor mass of size $15 \times 10 \times 8 \mathrm{~cm}$ (Figure 1).

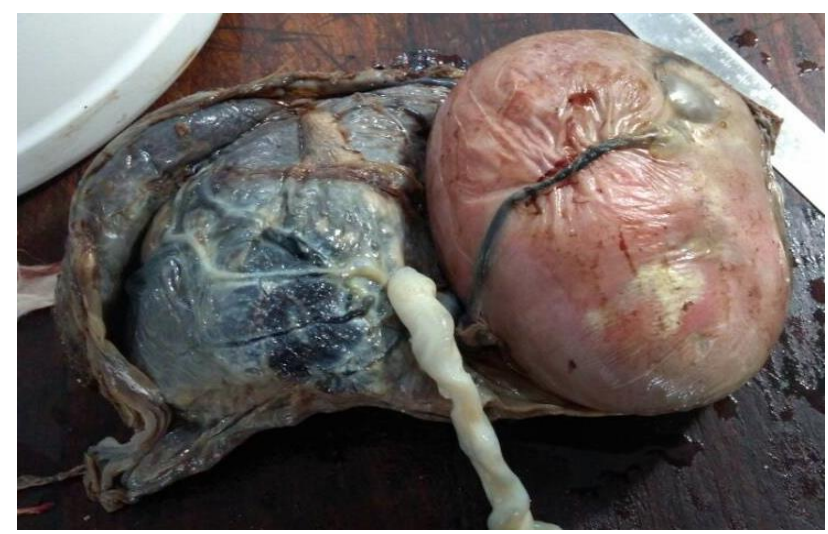

Figure 1: Showing gross specimen of placenta with cord and an oval tumor mass connected to it with a thin vessel.

Placental membranes and maternal surface of placenta were normal in appearance. Sections were taken from the umbilical cord and placenta including membranes. Tumor: The tumor was weighing 430 gms. The external surface was soft, few bosselations with occasional areas of hematoma were also noted. Consistency was variable from soft to firm with few hard areas suggestive of bone formations. Cut section showed variegated appearance with admixture of bony, myxoid, cartilaginous and soft areas (Figure 2).

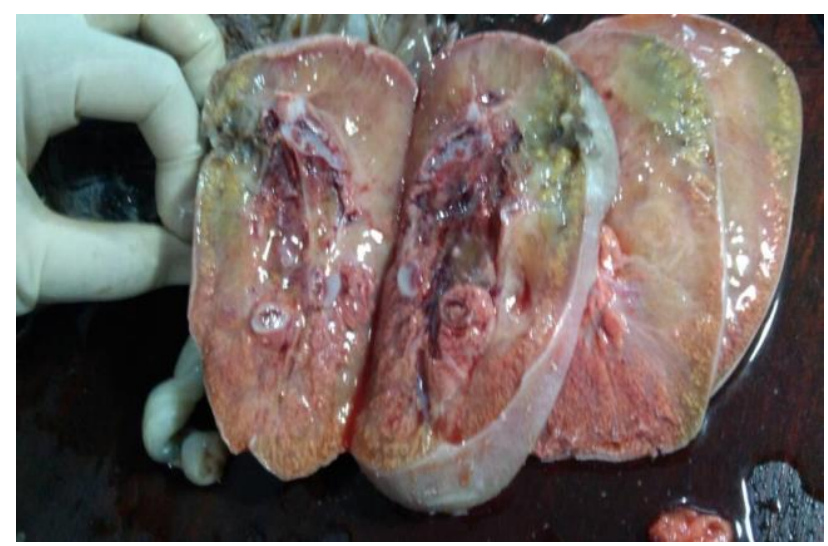

Figure 2: Showing cut section of the tumor mass showing variegated appearance with admixture of tissues with yellow, tan, myxoid, gelatinous areas and focal hemorrhages.

The tumor was subjected to radiological examination, which surprisingly revealed vertebral bodies along with ribs and pelvic bone formations (Figure 3). However cranial bones were not visualized clearly. Multiple sections were taken from different areas of the mass and subjected to histological examinations.

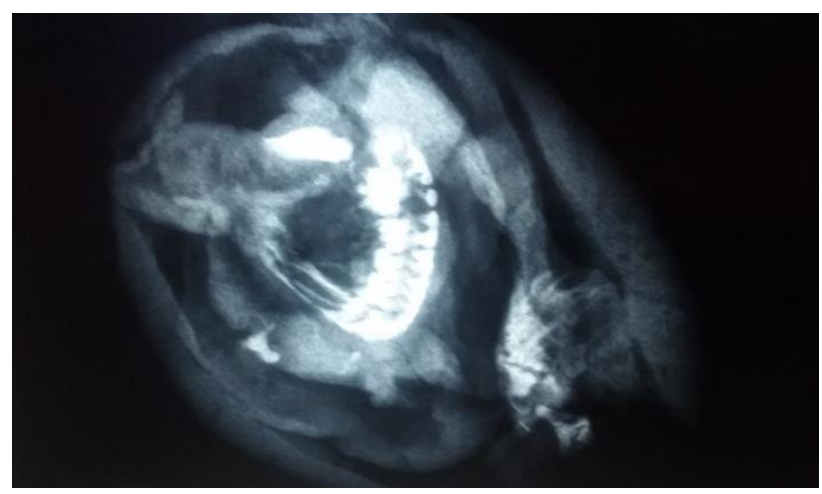

Figure 3: Radiograph of the specimen showing vertebral column, pelvic bones and rib like structures. Cranial bones are not seen.

\section{Histopathology}

Sections showed normal appearing epidermis with underlying adnexal structures including hair follicles, sebaceous glands, and eccrine glands. Adipose tissue, muscle, lymphoid tissue, glandular structures and thyroid tissue were also seen (Figure 4). In view of presence of connecting vessel from umbilical cord and admixture of all tissues, the diagnosis of Fetus Acardius Amorphous was offered.

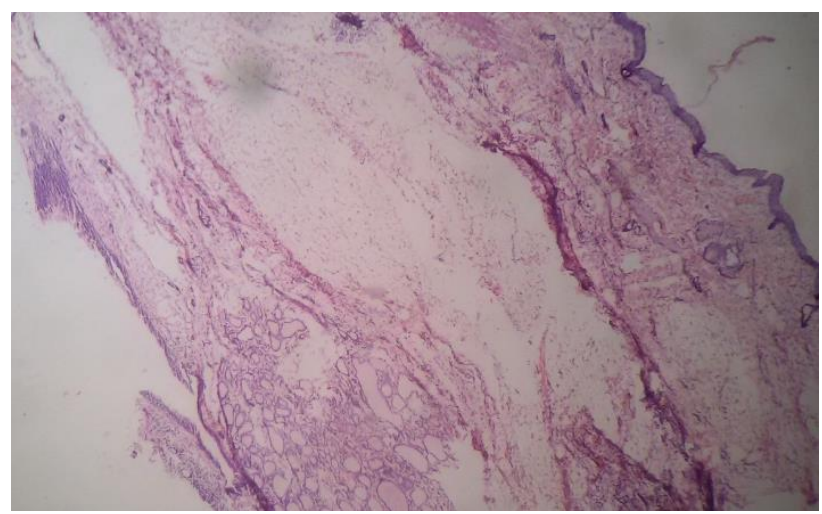

Figure 4: Section from the tumor mass showing normal appearing epidermis with adnexal structures and underlying tissues consisting of adipose tissue, muscle, glandular structures and thyroid tissue.

\section{DISCUSSION}

Acardiac anomaly sequence is a rare malformation cluster occurring in the setting of monozygotic monochorionic twin pregnancies. We report a description of one new case of fetus acardius amorphous. Buyukkaya A found that mortality is $100 \%$ in acardiac twin. Mortality of pump twin is around $50 \%$ and death is usually due to 
heart failure and sometimes prematurity caused by polyhydramnios. $^{2}$

Melvin D et al found that since the report of the first case by Benedetti in 1533 to the present, only sixty-three cases of acardius amorphus have been reported in the medical literature. ${ }^{4}$ As have been reported previously, the more severe forms of acardiac twin have been misdiagnosed antenatally as placental or uterine masses or teratoma by ultrasonography. Due to the parasitic hemodynamic dependence of the acardiac twin on the pump twin, it is important to monitor the pump twin for signs of decompensation and, if indicated, intervene by interrupting vascular supply to the acardiac twin. The goal of treatment is to maximize the pump-twin's chance of survival.

The first line of treatment, if available, should be ultrasound-guided laser coagulation or radiofrequency ablation of the intrafetal vessels. ${ }^{5}$ In present case, as our patient had fetal distress, she was immediately taken for emergency caesarean section. A full term normal baby weighing $2.4 \mathrm{~kg}$ was delivered by lower segment caesarean section (LSCS) and a tumor of $15 \times 10 \times 8 \mathrm{~cm}$ was seen attached to placenta. The pump baby was normal and revealed no signs of cardiac failure or any other abnormality.

Melvin D et al found that acardii amorphi have been described as being of various shapes as: egg-shaped, reniform, globose, triangular, oval, etc. ${ }^{4}$ In present case, it was oval mass connected well to placenta directly with a thin walled vessel. This feature is most important to differentiate it from placental teratoma.

Wong AE et al reported that it is highly unusual for a teratoma to have such a high degree of organization. It has been proposed that the distinction between fetus amorphous acardius and teratoma is arbitrary, since they probably represent the two portions of a continuum. However, the two entities have a different origin (teratoma is a neoplasm whereas fetus amorphous acardius is a fetal malformation) and different impact on the other embryo.

Teratomas are rarely associated with fetal distress. ${ }^{5}$ Wong $\mathrm{AE}$ et al reported that it is always accompanied by the presence of a cotwin, since it needs the functioning heart of the other embryo to provide circulation for both of them. $^{5}$

Our case is a rare condition and needs to be differentiated from Placental teratoma both on morphology as well as radiology. Diagnostic criteria for fetus acardius amorphous include presence of a separate vessel from umbilical cord and presence of organized skeletal structures confirmed on radiology. Since both the criterion were fulfilled in this case, the diagnosis of Fetus Acardius amorphous could be given.
Kamitomo M. reported that a single artery in the umbilical cord is seen in $50 \%$ of cases. The prenatal diagnosis of an acardiac fetus can be difficult.

Diagnostic criteria by ultrasound usually include: absent cardiac motion, poorly defined head and trunk, increase in soft tissue mass and existence of reverse blood flow through the umbilical cord. In some cases, the diagnosis of acardia was established at autopsy. ${ }^{9}$ the degree of skeletal organization and umbilical cord formation form the basis of diagnosis of this condition. ${ }^{10}$

Rohilla $M$ et al reported that after exclusion of chromosomal aberrations and malformations of the pump twin, close sonographic follow-up may be initiated. If the estimated weight of the acardiac twin is less than one fourth of the pump twin, the prognosis is excellent without further therapy. The current information on early recognition and treatment for salvation of the normal twin is based on individual case reports in the literature. ${ }^{11}$

\section{CONCLUSION}

The acardiac anomaly is a rare condition found only in monozygotic multiple pregnancies, usually twins. Hence this case is reported.

\section{Funding: No funding sources \\ Conflict of interest: None declared \\ Ethical approval: Not required}

\section{REFERENCES}

1. Chanthasenanont A, Pongrojpaw D. Acardiac twin. J Med Assoc Thai. 2005 Nov;88(11):1721-4.

2. Buyukkaya A, Tekbas G, Buyukkaya R. Twin Reversed Arterial Perfusion (TRAP) sequence; characteristic gray-scale and doppler ultrasonography findings. Iran J Radiol. 2015 Jul 22;12(3):e14979.

3. Nanthakomon T, Chanthasenanont A, Somprasit C, Manusook S, Pongrojpaw D, Suwannarurk K. Twin Reversed Arterial Perfusion (TRAP) sequence: a case report and review of treatment. J Med Assoc Thai. 2015 Apr;98 Suppl 3:S132-40.

4. Kappelman MD. Acardius amorphus. Am J Obstet Gynecol. 1944 Jan 1;47(3):412-6.

5. Wong AE, Sepulveda W. Acardiac anomaly: current issues in prenatal assessment and treatment. Prenat Diagn. 2005 Sep;25(9):796-806.

6. Schwarzler P, Ville Y, Moscosco G, Tennstedt C, Bollmann R, Chaoui R. Diagnosis of twin reversed arterial perfusion sequence in the first trimester by transvaginal color Doppler ultrasound. Ultrasound Obstet Gynecol. 1999;13(2):143-6.

7. Langlotz H, Sauerbrei E, Murray S. Transvaginal Doppler sonographic diagnosis of an acardiac twin at 12 weeks gestation. J Ultrasound Med. 1991;10(3):175-9.

8. Hecher K, Ville Y, Nicolaides KH. Color Doppler ultrasonography in the identification of 
communicating vessels in twin-twin transfusion syndrome and acardiac twins. J Ultrasound Med. 1995;14(1):37-40.

9. Kamitomo M, Kouno S, Ibuka K, Oku S, Sueyoshi $\mathrm{K}$, Maeda $\mathrm{T}$ et al. First-trimester findings associated with twin reversed arterial perfusion sequence. Fetal Diagn Ther. 2004;19:187-190.

10. Zelepi VT, Zolota V, Mavromati E. Fetus amorphous acardious: report of a rare case and differential diagnosis from placental teratoma with review of the literature. Eur Rev Med Pharmacologic Sci. 2007;11:419-422.
11. Rohilla M, Chopra S, Suri V, Aggarwal N, Vermani N. Acardiac-acephalus twins: a report of 2 cases and review of literature. Medscape $\mathrm{J}$ Med. 2008;10(8):200.

Cite this article as: Bhat DM, Butale PR, Kumbhalkar DT, Raut WK. Fetus acardius amorphous: a rare case report. Int J Reprod Contracept Obstet Gynecol 2017;6:4686-9. 